www.jmscr.igmpublication.org

Impact Factor 5.84

Index Copernicus Value: 71.58

ISSN (e)-2347-176x ISSN (p) 2455-0450

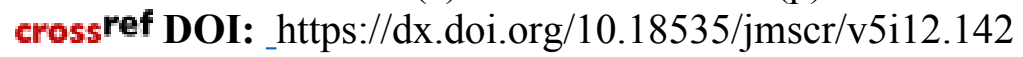

Journal Of Medical Science And Clinical Research

\title{
Evaluation of Best Marker in the Diagnosis of Various Liver Diseases
}

\author{
Authors
}

\section{Dr M. Madan Mohan Rao ${ }^{1}$, Dr P.Rajeswari2*, G. Obulesu ${ }^{3}$, Salma Mahaboob R ${ }^{4}$}

${ }^{1}$ Associate Professor, General Medicine at Rajiv Gandhi institute of Medial Sciences, Kadapa, Andhra Pradesh. India

${ }^{* 2}$ Assistant Professor, Biochemistry at Fathima institute of Medial Sciences, Kadapa, Andhra Pradesh India

${ }^{3}$ Assistant Professor in Microbiology at Kerala Medical College, Pallakad, Kerala, India

${ }^{4}$ Assistant Professor, Biochemistry at Fathima Institute of Medial Sciences, Kadapa, Andhra Pradesh India *Corresponding Author

\section{Dr P.Rajeswari}

Assistant Professor, Biochemistry, Fathima Institute of Medical Sciences, Kadapa, Andhra Pradesh India

Email: prasanthmammila@gmail.com

\begin{abstract}
The liver has a central \& critical bio-chemical role in metabolism, digestion, detoxification \& elimination of substances from the body. All blood from the intestinal tract initially passes through the liver, where products derived from digestion of food are processed, transformed \& stored. These include amino acids, carbohydrates, fatty acids, lipids, vitamins \& minerals.
\end{abstract}

Aim: To study the best markers in the diagnosis of various liver diseases.

Materials and Methods: The present study was done in the department of General Medicine at Rajiv Gandhi Institute of Medical Sciences, Kadapa, Andhra Pradesh, India. The present study was carried out on total 100 subjects aged between 40-65 years. Subjects were divided into 4 groups. 25 subjects were cirrhosis of liver and 25 were alcoholic liver disease and 25 were suffering from viral hepatitis. Control group which consist of 25 subjects who had no complain and history of liver disease.

Conclusion: Estimation of these parameters is a guide for assessment of severity of the damage to the liver as also a good prognostic value. Irrespective of the ethiology of liver estimation of these parameters substantially provides complete picture of liver disease.

Keywords: Cirrhosis of liver, Alcoholic Liver disease, Viral Hepatitis, ALP.

\section{Introduction}

The liver has a central \& critical bio-chemical role in metabolism, digestion, detoxification \& elimination of substances from the body. All blood from the intestinal tract initially passes through the liver, where products derived from digestion of food are processed, transformed \& stored. These include amino acids, carbohydrates, fatty acids, lipids, vitamins \& minerals ${ }^{[1-3]}$.
The incidence of traumatic liver injury in 1996 and 1997 was 2.95/100 000 annually. Seventy seven autopsies with liver injuries revealed injury pattern of grade I in 6 cases (8\%), grade II in 10 cases $(13 \%)$, grade III in 21 cases $(27 \%)$, grade IV in 15 cases $(19 \%)$, grade $\mathrm{V}$ in 16 cases $(21 \%)$ and grade VI in 9 cases $(12 \%)$. Twenty four patients revealed injury pattern of grade II in 13 cases $(46 \%)$, grade III in 4 cases $(14 \%)$, grade IV in 5 cases $(18 \%)$ and grade $\mathrm{V}$ in 2 cases $(7 \%)^{[4-5]}$. 
Metabolism of carbohydrates, fats and protein synthesis of bile and prothrombin Excretion of rugs, toxins, poisons, cholesterol, bile pigments and heavymetals, Protective by conjugation, destruction, phagocytosis, antibody formation and excretion and Storage of glycogeniron, fat, vitamin $\mathrm{A}$ and $\mathrm{D}$.

Liver disease is a general term for any damage that reduces the functioning of the liver. As a large organ, the liver shares with many other organs the ability to perform its functions with extensive reserve capacity ${ }^{[6]}$.

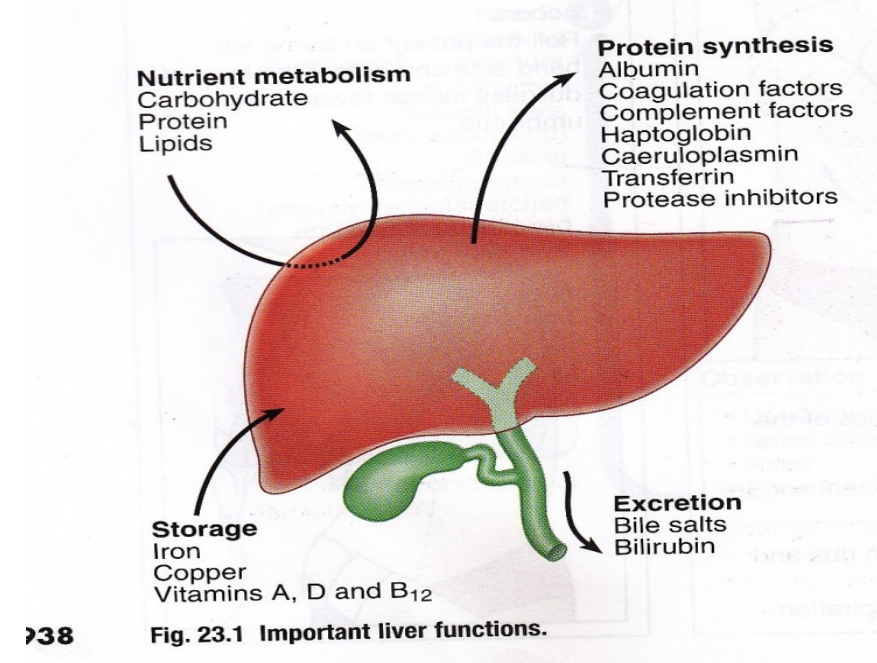

\section{Functions of Liver}

Metabolism of carbohydrates, fats and proteins

$\square$ Synthesis of bile and prothrombin

$\square$ Excretion of drugs, toxins, poisons, cholesterol, bile pigments and heavy metals

$\square$ Protective by conjugation, destruction, phagocytosis, antibody formation and

excretion and Storage of glycogen, iron, fat, vitamin A and D [7-9].

\section{Classification of Liver Diseases}

Liver diseases classified as

1. Hepatocellular: - Viral hepatitis, alcoholic liver disease.

2. Cholestatic: Gall stone malignant obstruction. Primary biliary cirrhosis some drug, induced liver Disease.
3. Mixed:- Features of both hepatocellular \& cholestatic injury are present ${ }^{[8]}$.

\section{Other Classification of Liver Disease Acute Liver Disease}

$\square$ Viral hepatitis is the most common cause, worldwide.

$\square \quad$ Phalloides poisoning

$\square \quad$ In pregnancy

$\square \quad$ In Wilson's disease.

\section{Chronic Liver Disease}

Chronic liver diseases includes: Cirrhosis of liver Alcoholic liver disease

$$
\begin{array}{r}
\text { Viral hepatitis - HBV } \\
\text { HDC } \\
\text { HCV }
\end{array}
$$

Wilson's disease

Hepatocellular carcinoma of liver ${ }^{[9-11]}$.

Chronic alcoholic liver disease differs clinically \& bio-chemically from other forms of hepatitis \& liver disease. Both alcoholism \& susceptibility to the development of cirrhosis appear to be largely genetically determined in that only $10 \%$ to $15 \%$ as heavy consumers of alcohol develop cirrhosis of liver ${ }^{[12-14]}$.

Both hepatitis B\& C appear to accelerate the course of alcoholic liver disease. The survival rate in patients with cirrhosis is five year, jaundice and ascitis is $40 \%$ if the patient continues drinking \& $60 \%$ if the patient abstains ${ }^{[15]}$.

\section{Materials and Methods}

The present study was done in the department of General Medicine at Rajiv Gandhi Institute of Medical Sciences, Kadapa, Andhra Pradesh, India. The present study was carried out on total 100 subjects aged between $40-65$ years. Subjects were divided into 4 groups. 25 subjects were cirrhosis of liver and 25 were alcoholic liver disease and 25 were suffering from viral hepatitis. Control group which consist of 25 subjects who had no complain and history of liver disease.

Informed consent was taken from both cases and controls and the study was approved by the 
institutional ethical and research committee. A detailed proforma was filled up for each patient which included age, sex, past history of coronary artery disease, cerebrovascular accident, history of hypertension.

Blood samples were collected, analyzed. Blood was collected in plain tubes for serum, the samples were separated by centrifugation \& serum was used for the estimation of SGOT, SGPT,ALP \& Bilirubin and Gamma glutamyl transferage.

Statistical Analysis: The results obtained and expressed in mean \pm SD. The comparison was done by student $t$ test and statistical analysis of each parameter was done by SPSS statistical package version 15.0. $\mathrm{p}$ value $<0.05$ was considered statistically significant.

\section{Results}

The present study was carried out on total 100 subjects aged between 40-65 years. Subjects were divided into 4 groups. 25 subjects were cirrhosis of liver and 25 were alcoholic liver disease and 25 were suffering from viral hepatitis. Control group which consist of 25 subjects who had no complain and history of liver disease.

Table 1: Comparision of Statistical Analysis of Liver Enzymes in Various Liver Diseases

\begin{tabular}{|l|c|c|c|c|c|}
\hline PARAMETERS & $\begin{array}{c}\text { CIRRHOSIS } \\
\text { OF LIVER }\end{array}$ & $\begin{array}{c}\text { ALCOHOLIC } \\
\text { LIVER DISEASE }\end{array}$ & VIRAL HEPATITIS & CONTROLS & P.Value \\
\hline BILIRUBIN & & & & & \\
MEAN & 5.05 & 6.8 & 3.3 & 0.9 & \\
SD & 1.5 & 1.2 & 4.6 & 0.3 & $<0.005$ \\
\hline SGOT & 333.8 & 392 & 414.2 & 45 & $<0.001$ \\
MEAN & 80.3 & 69 & 45.8 & 12 & \\
SD & 362.8 & 409 & 459.3 & 43 & $<0.005$ \\
\hline SGPT & 72.9 & 45 & 62.6 & 14 & \\
MEAN & & & 410 & 85 & $<0.001$ \\
SD & 330.6 & 377.5 & 20.6 & 23 & \\
\hline ALP & 74.9 & 60.2 & & & \\
MEAN & & & & & \\
SD &
\end{tabular}

Graph 1: Distribution of Various Liver Diseases Based on Etiology

1. Cirrhosis of Liver

2. Alcoholic Liver Disease

3. Viral Hepatitis

4. Controls

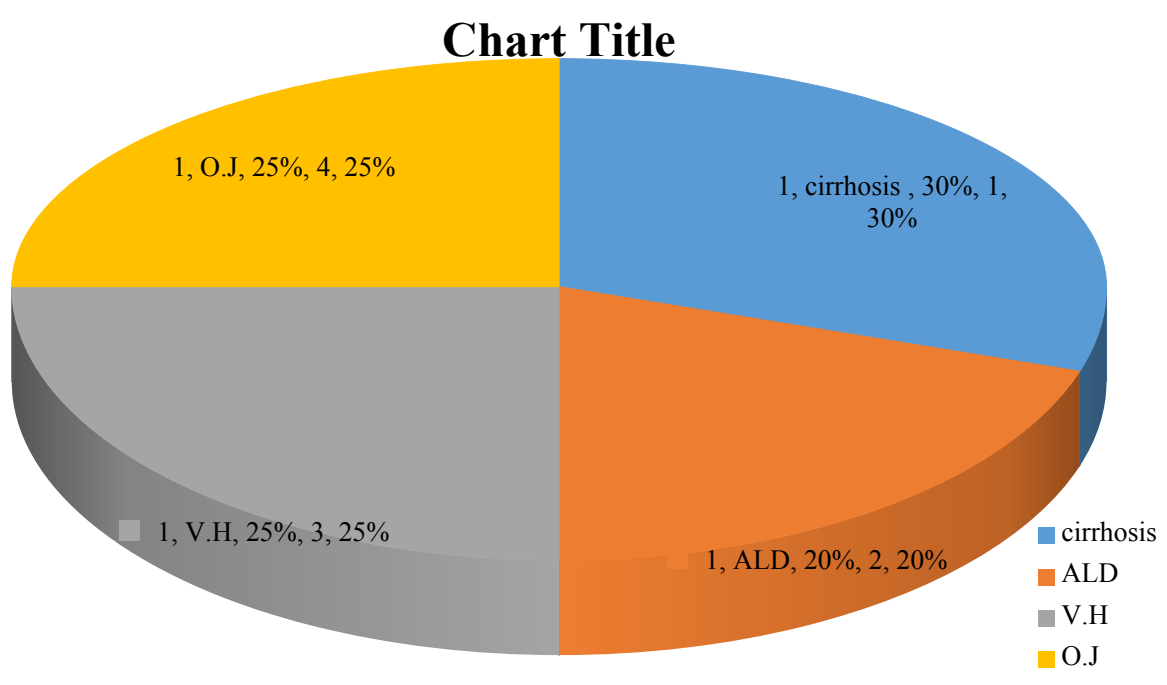




\section{Discussion}

The present study involves estimation of parameters relating to inflammatory process, defense mechanism of the individual and also the products for damage caused to the cells in liver diseases. The estimated parameters or enzymes Bilirubin, SGOT, SGPT \& ALP AND related to hepatocellular damage.

In the present study shows that the mean \& SD of Bilirubin in Cirrhosis of liver disease $5.05 \pm 1.5$. The mean \& SD of SGOT in Cirrhosis of liver disease $333.8 \pm 80.3$. The mean $\&$ SD of SGPT in Cirrhosis of liver disease $362.8 \pm 72.9$. The mean $\&$ SD of ALP in Cirrhosis of liver disease $330.6 \pm$ 74.9. The mean \& SD of Bilirubin in Alcoholic liver disease $6.8 \pm 1.2$. The mean $\&$ SD of SGOT in Alcoholic liver disease $392 \pm 69$. The mean \& SD of SGPT in Alcoholic liver disease $409 \pm 45$. The mean \& SD of ALP in Alcoholic liver disease $377.5 \pm 60.2$. The mean \& SD of Bilirubin in Viral Hepatites $3.28 \pm 0.68$. The mean \& SD of SGOT in Viral Hepatites 414.2 \pm 75.8 . The mean $\&$ SD of SGPT in Viral Hepatites $459.2 \pm 62.6$. The mean \& SD of ALP in Viral Hepatites $410 \pm$ 20.6.in controls all the values are normal.

Estimation of these parameters is a guide for assessment of severity of the damage to the liver as also a good prognostic value. Irrespective of the ethiology of liver estimation of these parameters substantially provides complete picture of liver disease.

\section{Conclusion}

Estimation of these parameters is a guide for assessment of severity of the damage to the liver as also a good prognostic value. Irrespective of the ethiology of liver estimation of these parameters substantially provides complete picture of liver disease. The present study it is observed that in alcoholic Liver Disease shows a highest rise in Gama glutamyl transferase and ALP levels, high levels of GGT lives are the markers in the diagnosis of alcoholic liver disease. In cirrhosis of liver SGOT and SGPT levels are high these shows that these are the marker enzyme for cirrhosis of liver. in viral hepatitis ALP,SGOT and SGPT levels are significantly sigh when compare to controls. But for the investigation of are required for the diagnosis of liver.

\section{References}

1. Davidge RC, Philpot, GR Differential diagnosis of liver disease by serum 5 'NT. Proc. Assoc. Clin. Biochem. 1966;4: 36-41.

2. Sibley JA, Higgins GM, Fleisher GA. Serum aldolase in experimental liver necrosis. Arch. Pathol. 1955 ;59: 712-17

3. Rose CI, Henderson AR.The clinical significance of sorbitol dehydrogenase Clin. Chem.1975; 21:956-62

4. Davisons. The principles and practice of medicine,.21st edition 2010.p 922-969.

5. Curtis SJ, Mortiz M, Snodgrass PJ. Serum enzymes derived from liver cell fractions. The response to carbon tetrachloride intoxication in rats. Gastroenterol.1972; 62: 84-91.

6. Wolf PL. Biochemical diagnosis of liver diseases. Ind.J.Clin.Biochem.1999;14: 5990.

7. King FJ, Wooton IDP. In: Microanalysis in Medical Biochemistry. 3rd ed, Pub. J \& A Churchil Ltd, London p. 83,1956.

8. Varley, H. In: Practical Clinical Biochemistry. $4^{\text {th }}$ ed. Arnold Heinman. (India) Ltd. New Delhi p 465,1975.

9. Harrison. Harrisons principles of internal medicine,.17th edition, II volume p.19181980.

10. Bauer JD, Ackerman PG, Tom G. In : Methods in Clinical Chemistry. 8th ed. C.V. Mosby Co. St.Louis., USA p $472,1974$.

11. Rose CI, Henderson AR. Reaction rate assay of serum sorbitol dehydrogenase activity at $37 \sim$ C. Clin.Chem.1975; 21 :1619-1624.Indian Journal of Clinical Biochemist 2000, 15 (1), 48-51

12. Ellis G, Goldberg DM, Spooner RJ, Ward MA. Serum enzyme tests in diseases of 
liver and biliary tree. Am. J.Clin. Pathol. 1978; 70: 248-54.

13. Boone DJ. Routh J1. A comparison of 5' Nucleotidase (NTP) and gama glutamyl transpeptidase (GGTP) as diagnostics of liver disease. Clin. Chem.1973;19: 656-62.

14. Goldberg DM. 5'Nucleotidase: Recent advances in cell biology, methodology and clinical significance. Digestion.1973; 8: 87-92.

15. Raghavendra DS, Srinivas B.Rao. Studies on some serum enzyme levels in various liver diseases. Indian journal of clinical biochemistry. 2000;15(1):48-51. 